\title{
In vitro Anti-Bacterial Activity of Oral Herbal Medicines Assessed by Agar Well Diffusion and Broth Micro-Dilution Methods
}

\author{
Kamal Kanta Das, Mrityunjoy Acharjee and Rashed Noor \\ Department of Microbiology, Stamford University Bangladesh, 51 Siddeswari Road, Dhaka 1217, Bangladesh
}

\begin{abstract}
Recently antibacterial activity of ten commonly available oral herbal medicines has tested in our laboratory. Current investigation further endeavoured to compute the microbial propagation in six more oral herbal medicines, including the drug resistance pattern of the microbial isolates, and antibacterial potential of the medicines by employing both agar well diffusion method and broth micro-dilution procedure to determine the minimum inhibitory concentration (MIC). Among the 30 samples of 6 categories studied, the total viable bacteria were found within the range of $10^{4}-10^{7} \mathrm{cfu} / \mathrm{ml}$, while the presence of fungi was noticed only in 3 samples up to $10^{5} \mathrm{cfu} / \mathrm{ml}$. All samples were found to be contaminated with Staphylococcus spp., 2 samples with Escherichia coli and 1 sample was found to be contaminated with Klebsiella spp. Most of the isolates showed resistance against commonly used 13 antibiotics; $80 \%$ isolates were found to be multidrug-resistant (MDR). All samples exhibited antibacterial activity with their MIC values up to $55 \mathrm{mg} / \mathrm{ml}$. However, using the agar well diffusion assay, antibacterial activity was detected only in case of only 1 sample.
\end{abstract}

Keywords: Drug resistance, In vitro antibacterial activity, Oral herbal medicines, Minimum inhibitory concentration (MIC)

\section{Introduction}

Besides the vast use of synthetic drugs (i.e., antibiotics) in disease mitigation, herbs and herbal products may claim no less importance as the primary health care mediators ${ }^{1-2}$. Considering the ease of availability, economic benefit, low rate of side effects, scientists focused their attention on the herbs to formulate the new drugs since $1996^{1-3}$. According to the WHO report, during 1998-2002, more than 21,000 plants have been used for medicinal purposes round the globe ${ }^{4-5}$. An important aspect of using huge amount of antibiotics comes up with the emergence of drugresistant bacteria in food, water and pharmaceutical products which in turn may bring serious obstacle in disease medication as well as may reduce the rate of self immune response ${ }^{1,6-7}$. Conversely, several studies have revealed that the herbs and herb extracts can effectively reduce the pathogenic propagation with the minor side effects and small toxicity ${ }^{8-11}$. Moreover, compared with the synthetic antibiotics, herbal medicines may also be effective in managing the dissemination of drug-resistant pathogenic microorganisms ${ }^{1-2,8}$. Interestingly, the previous facts of antibacterial properties of herbal medicines open the avenue for a detailed microbiological investigation on the available herbal products for the sake of public health management especially in the developing countries with mass population ${ }^{1-2,12}$.

In Bangladesh, several pharmacological assessment and ethnomedicinal investigations have been conducted on the medicinal plants as well as the herbal medicines, which indeed escort the necessity of the demonstration of proper microbiological profiling of the herbs and herbs products ${ }^{1-2,12}$. Moreover, finding of antibacterial activity significantly in $50 \%$ of the 10 categories of herbal medicines along with the recovery of drug resistant microbes in the same samples by our recent study urged the quintessence of investigating other herbal products ${ }^{1-2}$. Thus our current study fostered on to evaluate microbiological contamination level within 6 more commonly available herbal medicines, and to demonstrate their antibacterial aptitude.

\section{Methods}

Study site, sampling and sample processing

Five samples of each of six different categories of commercially available oral herbal drugs in liquid formulations were randomly collected from different medicinal stores in Dhaka City during September through November 2014. The medicaments used included Sample 1: Skin care (MXN Homooeo Laboratories), Sample 2: Decnar (MarcoUnani Pharma), Sample 3: Sharbat Ejaz (MarcoUnani Pharma), Sample 4: Cinkara (Hamdard, Waqf), Sample 5: Marbelus (Hamdard Unani Products) and Sample 6: Devas (Drug International Ltd.). The manufacturing and expiry dates at the time of sampling were found to be satisfactory. The samples were processed aseptically according to the guidelines of American Public Health Association ${ }^{1}$ followed by homogenization of $25 \mathrm{ml}$ of each samples with $75 \mathrm{ml}$ normal saline and then diluted up to $10^{-5}$ for the enumeration of potential pathogenic bacteria and fungi ${ }^{1-2}$.

*Corresponding author:

Rashed Noor, Department of Microbiology, Stamford University Bangladesh, 51 Siddeswari Road, Dhaka 1217, Bangladesh

Tel: +880 (02) 8355626,E-mail: noor.rashed@yahoo.com 


\section{Microbiological analysis}

An aliquot of $0.1 \mathrm{ml}$ of each sample from the dilutions $10^{-2}$ and $10^{-}$

${ }^{4}$ was introduced employing the spread plate technique onto the nutrient agar (NA) and Sabouraud's dextrose agar (SDA) plates for the estimation of total viable bacteria (TVB) and fungi respectively. Plates were incubated at $37^{\circ} \mathrm{C}$ for 24 hours and at $25^{\circ} \mathrm{C}$ for 48 hours for bacterial and fungal growth observations, respectively. Membrane faecal coliform (MFC) agar and MacConkey agar were used for the quantification of total faecal coliform (TFC), and coliforms (Escherichia coli and Klebsiella spp.), respectively. Likewise, Staphylococcus spp. and actinomycetes were isolated on mannitol salt agar (MSA) and actinomycetes agar, respectively. All plates were incubated at $37^{\circ} \mathrm{C}$ for 24 hours, while for the observation of the growth of faecal coliforms, plates were incubated at $44.5^{\circ} \mathrm{C}$ for 24 hours ${ }^{1-2}$.

\section{Isolation of Salmonella, Shigella and Vibrio}

An aliquot of $10 \mathrm{ml}$ sample was transferred into $90 \mathrm{ml}$ of selenite cysteine broth (SCB) and alkaline peptone water (APW) for the enrichment of Salmonella, Shigella and Vibrio, respectively and incubated at $37^{\circ} \mathrm{C}$ for 6 hours ${ }^{1-2}$. After incubation, $0.1 \mathrm{ml}$ of samples (with optical density of 0.3 , measured by spectrophotometer at 600 $\mathrm{nm}$ ) from each of the $10^{-2}$ and $10^{-4}$ dilutions were spread onto Salmonella-Shigella (SS) agar and thiosulfate citrate bile salt sucrose (TCBS) agar for the isolation of Salmonella spp. and Shigella spp. and Vibrio spp., consecutively. Plates were incubated at $37^{\circ} \mathrm{C}$ for 48 hours for the detection of the desired isolates. Finally, all the isolates were biochemically examined following standard procedures as described earlier ${ }^{13}$.

\section{Antibiotic susceptibility test}

Antibiotic susceptibility traits of the pathogenic isolates were examined by using the commercially available laboratory grade antibiotic discs of ampicillin $(10 \mu \mathrm{g})$, ciproofxacin $(5 \mu \mathrm{g})$, streptomycin $(10 \mu \mathrm{g})$, ceftriazone $(30 \mu \mathrm{g})$, imipenem $(30 \mu \mathrm{g})$, penicillin $(10 \mu \mathrm{g})$, gentamicin $(10 \mu \mathrm{g})$, azithromycin $(15 \mu \mathrm{g})$, tetracycline (30 $\mu \mathrm{g})$, cefuroxime (5 $\mathrm{g}$ ), erythromycin (15 $\mu \mathrm{g})$, chloramphenicol $(10 \mu \mathrm{g})$ and salfamethxazole $(25 \mu \mathrm{g})$. Discs were aseptically placed over the surface of Mueller-Hinton agar plates (Difco) at spatial distance of $5 \mathrm{~mm}$, which had been previously inoculated with the pathogenic test bacterial suspensions (i.e., bacterial lawn as previously described) ${ }^{6}$.

Determination of antibacterial activity of herbal medicine samples through agar well diffusion method

The in vitro antibacterial activity of the samples was detected as described in our recent study ${ }^{1}$. At first, the bacterial suspensions (with standard turbidity compared to that of the McFarland standard of 0.5) of Pseudomonas spp., Listeria spp., Bacillus spp., Vibrio spp., Salmonella spp., Klebsiella spp., Staphylococcus spp. and E. coli was spread evenly over the Mueller-Hinton agar using cotton swabs. Wells were made by means of the sterile cork-borer, and an aliquot of $100 \mu$ of each samples was introduced into the specified wells with a residual concentrations of 3.4, 2.4, 0.6, 1.4, 0.5 and $0.8 \mathrm{mg} / \mathrm{ml}$ for samples 1 , $2,3,4,5$, and 6 , consecutively in the specified well along with a positive control (gentamicin, $10 \mu \mathrm{g}$ ) and a negative control (normal saline) ${ }^{1}$. Presence of clear zone was indicative of the active compound of the tested samples against the pathogens ${ }^{1}$.
Determination of antibacterial activity of herbal medicine samples using broth micro-dilution method

Estimation of the MIC of the samples was demonstrated as described in our study earlier ${ }^{1}$. This method could notice the minimum concentration of each herbal medicine capable to reduce the cell division rate of the tested bacteria ${ }^{1}$. Each of the test bacteria (100 $\mu$ l of overnight culture adjusted with $0.5 \mathrm{McF}$ arland standard) was inoculated into the appropriately labelled sterile tubes containing Mueller-Hinton broth with a final volume of 3 $\mathrm{ml}$ (Mueller-Hinton broth + samples + bacterial cells) ${ }^{1}$. The different volumes of samples were carefully used with $16,32,64$, $128,256,512$ and $1,024 \mu l^{1}$. All tubes were incubated at $37^{\circ} \mathrm{C}$ for 24 hours.

\section{Results and Discussion}

Propagation of microorganisms in herbal medicine samples

As consistent to our previous findings on 10 commonly available herbal medicines ${ }^{1}$, present study revealed a colossal occurrence of microbial contamination in rest of the 6 herbal medicine samples studied. All samples were found to harbour heterotrophic bacteria within the range of $10^{4}-10^{7} \mathrm{cfu} / \mathrm{ml}$. Among 6 samples, fungal contamination was noticed in 3 samples within the range of $10^{4}$ $10^{5} \mathrm{cfu} / \mathrm{ml}$ (Table 1). Nevertheless, contamination by specific pathogenic bacteria was low except for E. coli, Klebsiella spp. and Staphylococcus spp. $\left(10^{3}-10^{5} \mathrm{cfu} / \mathrm{ml}\right)$. Staphylococcal contamination was leading in all samples up to $10^{5} \mathrm{cfu} / \mathrm{ml}$ whereas E. coli was detected in 2 samples, and Kledsiella spp. was noticed in 1 sample (Table 1). The pathogens are assumed to get entrance into the medicines during the period of harvesting, processing, manufacturing, distribution or storage as has also been predicted in the earlier studies ${ }^{1-2,10,14-15}$.

Frequency of drug-resistant microorganisms in the herbal medicine samples

The development of drug-resistance gene within the human body is increasing day by day through the propagation of drug-resistant bacteria in water, food and pharmaceuticals ${ }^{6-7,16-17}$. Moreover, our previous study portrayed that Staphylococcus spp. and Klebsiella spp. were found to be resistant respectively against $20 \%$ and $60 \%$ of the antibiotics used ${ }^{1}$. As has been demonstrated in the current study, all 3 pathogenic isolates were resistant against multiple antibiotics tested (Table 2). Among the 3 pathogens, Klebsiella spp. and Staphylococcus spp. exhibited 100\% resistant against 8 and 5 antibiotics respectively, which denotes them as the MDR strain. However, E. coli revealed 50\% resistance and $50 \%$ sensitivity against the used antibiotics (Table 2). A number of studies have indicated that the development of drug resistant strain may create serious health threat and the antibiotic treatment complication and hence may pose the onset of secondary diseases within the body ${ }^{17,18}$. Routine microbiological examination of herbal medicines is thus mandatory to observe the existence of drug-resistant bacteria.

In vitro antibacterial activity of the herbal medicine samples Plants and plant extracts play an important role for disease medication and are also popular to the people not only in Bangladesh, but also to the $80 \%$ of global population for the intended use for homeopathy, Ayurveda, Unani, folk medicines 
Table 1. Microbiological profile of the commonly available herbal medicine

\begin{tabular}{lccccc}
\hline Sample & \multicolumn{3}{c}{ Count $(\mathrm{cfu} / \mathrm{ml})$} \\
& TVB & Fungi & Escherichia coli & Klebsiella & Staphylococcus \\
\hline Sample $1(\mathrm{n}=5)$ & $2.6 \times 10^{7}$ & $2.6 \times 10^{5}$ & $7.8 \times 10^{4}$ & 0 & $2.9 \times 10^{5}$ \\
Sample 2 $(\mathrm{n}=5)$ & $1.5 \times 10^{6}$ & 0 & 0 & 0 & $7.0 \times 10^{3}$ \\
Sample 3 $(\mathrm{n}=5)$ & $1.9 \times 10^{5}$ & 0 & 0 & 0 & $1.5 \times 10^{3}$ \\
Sample 4 $(\mathrm{n}=5)$ & $1.1 \times 10^{7}$ & $1.8 \times 10^{4}$ & $1.0 \times 10^{3}$ & $1.0 \times 10^{3}$ & $2.0 \times 104$ \\
Sample 5 $(\mathrm{n}=5)$ & $6.4 \times 10^{4}$ & 0 & 0 & 0 & $2.4 \times 10^{3}$ \\
Sample 6 $(\mathrm{n}=5)$ & $1.1 \times 10^{7}$ & $2.6 \times 10^{5}$ & 0 & 0 & $2.3 \times 10^{4}$ \\
\hline
\end{tabular}

TVB = Total viable bacteria. Microbial limits: TVB - $10^{5} \mathrm{cfu} / \mathrm{ml}$; Escherichia coli $-10^{1} \mathrm{cfu} / \mathrm{ml}$; Salmonella - nil; Enterobacteria - $10^{3} \mathrm{cfu} / \mathrm{ml}$.

Table 2. Study of antibiotic susceptibility of different isolates from herbal medicine samples

\begin{tabular}{lcccccc}
\hline Antibiotic & \multicolumn{3}{c}{ Percent resistant $(\mathrm{R}) /$ sensitive $(\mathrm{S})$} & \\
& Escherichia coli $(\mathrm{n}=2)$ & \multicolumn{2}{c}{ Klebsiella $(\mathrm{n}=1)$} & \multicolumn{2}{c}{ Staphylococcus $(\mathrm{n}=8)$} \\
& $\mathrm{R}$ & $\mathrm{S}$ & $\mathrm{R}$ & $\mathrm{S}$ & $\mathrm{R}$ & $\mathrm{S}$ \\
\hline Ampicillin $(10 \mu \mathrm{g})$ & 50 & 50 & 100 & 0 & 100 & 0 \\
Ciprofloxacin $(5 \mu \mathrm{g})$ & 50 & 50 & 100 & 0 & 50 & 50 \\
Streptomycin $(10 \mu \mathrm{g})$ & 50 & 50 & 100 & 0 & 100 & 0 \\
Ceftriazone $(30 \mu \mathrm{g})$ & 50 & 50 & 0 & 100 & 50 & 50 \\
Imipenem $(30 \mu \mathrm{g})$ & 50 & 50 & 100 & 00 & 50 & 50 \\
Penicillin $(10 \mu \mathrm{g})$ & $\mathrm{ND}$ & $\mathrm{ND}$ & $\mathrm{ND}$ & $\mathrm{ND}$ & 90 & 10 \\
Gentamicin $(10 \mu \mathrm{g})$ & 0 & 100 & 0 & 100 & 0 & 100 \\
Azithromycin $(15 \mu \mathrm{g})$ & 50 & 50 & 100 & 0 & 20 & 80 \\
Tetracycline $(30 \mu \mathrm{g})$ & 100 & 0 & 100 & 0 & 80 & 20 \\
Cefixime $(5 \mu \mathrm{g})$ & 0 & 100 & 0 & 100 & 0 & 100 \\
Erythromycin $(15 \mu \mathrm{g})$ & 50 & 50 & 100 & 0 & 80 & 20 \\
Chloramphenicol $(10 \mu \mathrm{g})$ & 50 & 50 & 100 & 0 & 50 & 50 \\
Trimethoprin-salfamethxazole $(25 \mu \mathrm{g})$ & 0 & 100 & 0 & 100 & 0 & 100 \\
\hline
\end{tabular}

and home remedies ${ }^{12}$. Considering the mass public health management especially in the poor and developing countries, it is necessary to conduct the routine assay of the antibacterial activity of the frequently used herbal medicines besides the notification of their microbiological quality. Several reports have been published so far regarding the presence of antibacterial activity of the natural plants and plant extracts ${ }^{8-9,11}$ However, In Bangladesh, a number of studies have been initiated the existence of such antibacterial activity of the commonly available herbal medicines used by the people ${ }^{1,12}$. As the continuation of our recent findings, present study revealed such trend in 6 more commonly available herbal medicines. In case of agar well diffusion only 1 sample (sample 5) showed antibacterial activities against Salmonella spp. with the clear zone of inhibition of $22 \mathrm{~mm}$.

In addition, all the samples were further processed to demonstrate the in vitro antibacterial activity by broth micro-dilution procedure or the MIC assay (Table 3). As stated above, only 1 sample revealed antibacterial activity in case of agar well diffusion methods. Conversely, the assay of MIC revealed the antibacterial activity of the all tested samples against the bacterial isolates; i.e., E. coli, Klebsiella, Pseudomonas, Bacillus, Salmonella, Listeria, Staphylococcus and Vibrio. The MIC value was recorded for all samples within the range of $1 \mathrm{mg} / \mathrm{ml}$ (lowest) 55 $\mathrm{mg} / \mathrm{ml}$ (highest) (Table 3). The ideal MIC was recorded $22 \mathrm{mg} / \mathrm{ml}$ for sample 1 against all the tested pathogenic bacteria except Listeria spp. and Klebieilla, which was found to be inhibited at a concentration of $55 \mathrm{mg} / \mathrm{ml}$ and $34 \mathrm{mg} / \mathrm{ml}$ respectively. Significant MIC value (low to moderate) was found for the samples 2, 3 and 4. For sample 2, MIC was noticed at $11 \mathrm{mg} / \mathrm{ml}$ for the Klebsiella spp. and Salmonella spp., $8 \mathrm{mg} / \mathrm{ml}$ recorded for Bacillus spp. and Listeria spp., $5 \mathrm{mg} / \mathrm{ml}$ for Pseudomonas spp. and Staphylococcus spp., $1 \mathrm{mg} / \mathrm{ml}$ for E. coli and $3 \mathrm{mg} / \mathrm{ml}$ for Vibrio spp. For sample 3, the MIC was noticed at a maximal level of 10 $\mathrm{mg} / \mathrm{ml}$ to stall the bacterial growth. For sample 4, the MIC was recorded to be not more than $20 \mathrm{mg} / \mathrm{ml}$, E. coli, Salmonella spp. Staphylococcus spp., and Bacillus spp. was found to be inhibited at a concentration $10 \mathrm{mg} / \mathrm{ml}$ whereas Klebsiella spp., Pseudomonas spp., and Listeria spp. were inhibited at 15, 13 and $20 \mathrm{mg} / \mathrm{ml}$ consecutively. Only Vibrio spp. was found to be inhibited at a concentration of $5 \mathrm{mg} / \mathrm{ml}$. Sample 4 showed the MIC potential at $36 \mathrm{mg} / \mathrm{ml}$ against Klebsiella spp., Vibrio spp., Pseudomonas spp. and Listeria spp., $22 \mathrm{mg} / \mathrm{ml}$ concentration was recorded against Salmonella spp., Bacillus spp. and Staphylococcus spp., MIC was recorded for E. coli at $18 \mathrm{mg} / \mathrm{ml}$. In case of sample $6,18 \mathrm{mg} / \mathrm{ml}$ was recorded as the MIC against most of the tested pathogenic bacteria to inhibit the growth while $26 \mathrm{mg} / \mathrm{ml}$ were found to be effective against Klebsiella spp., Vibrio spp. and Listeria spp. (Table 3). 
Table 3. Antibacterial activity of the herbal medicine samples by broth micro-dilution procedure for the determination of the minimum inhibitory concentration (MIC) values

\begin{tabular}{lcccccc}
\hline & \multicolumn{5}{c}{ Test organismMIC values of herbal medicine samples (mg/ml) } \\
\cline { 2 - 7 } & Sample 1 & Sample 2 & Sample 3 & Sample 4 & Sample 5 & Sample 6 \\
\hline Escherichia coli & 22 & 1 & 10 & 10 & 18 & 18 \\
Klebsiella & 34 & 11 & 1 & 15 & 36 & 26 \\
Salmonella & 22 & 11 & 5 & 10 & 22 & 18 \\
Vibrio & 22 & 3 & 10 & 5 & 36 & 26 \\
Pseudomonas & 22 & 5 & 8 & 13 & 36 & 18 \\
Bacillus & 22 & 8 & 5 & 10 & 22 & 18 \\
Staphylococcus & 22 & 5 & 6 & 20 & 36 & 26 \\
Listeria & 55 & 8 & 5 & & & \\
\hline
\end{tabular}

Agar well diffusion test may not produce the suitable result by which the actual antibacterial traits can be detected possibly due to the diffusion deficiency across the solid agar ${ }^{1}$. In this study, when the result of agar well diffusion method were compared with the MIC, an absolute difference was evident, only 1 sample showed the antibacterial activity against a single bacteria whereas all the samples showed antibacterial activity against all the bacterial strains with very small concentrations (Table 3). As stated above, the diffusion rate of the active compound (responsible for possible antibacterial trait) of samples can be strongly hindered by the polarity, the concentration, the molecular size and sometimes for the rigidity of the media ${ }^{1,12}$.

\section{Conclusion}

The limited amount of pathogenic bacteria (only 3 isolates) in herbal medicine is quiet a good sign of product quality if they are in the acceptable range. However, presence of total viable bacteria and fungi as found in the current study were exceeding the marginal limit which is indeed evocative of implementing defined aseptic condition of manufacturing and processing of the herbal medicines. Presence of the MDR bacteria in the samples tested further may put forward the threat to the overall public health safety. However, presence of antibacterial traits of the samples ensured the effectiveness of the medicines against several disease complications. Collectively, $50 \%$ of the total 16 samples ( 3 out of 6 samples in the present study and 5 out of 10 in our recent study ${ }^{1}$ exhibited significant antibacterial activity as revealed from MIC assays. Such findings allow us suggesting the large scale application of herbs and herbal medicines by the registered professionals for the medication of diseases locally encountered.

\section{Acknowledgement}

We thank Microbiology Laboratory, Stamford University Bangladesh for laboratory facilities, technical assistance and financial aid.

\section{References}

1. Sharmin M, Nur IT, Acharjee M, Munshe SK and Noor R. 2014. Microbiological profiling and the demonstration of in vitro antibacterial traits of the major oral herbal medicines used in Dhaka Metropolis. SpringerPlus. 3: 739.

2. Quaiyum S, Tanu NI, Sharmin M, Poul L, Munna S, Das KK, Acharjee $\mathrm{M}$ and Noor R. 2014. Microbiological contamination and antibacterial traits of common oral herbal medicinal products within Dhaka metropolis. Eur J Medicinal Plant. 4 (7): 872-881.

3. Razmavar S, Abdulla MA, Ismail SB and Hassandarvish P. 2014. Antibacterial activity of leaf extracts of baeckea frutescens against methicillin-resistant Staphylococcus aureus. BioMed Res Int. 2014: $1-5$.

4. Umashanker M and Shruti S. 2011. Antipyretic, antiulcer, anti-diabetic and anticancer: A review. Int J Res Pharm Chem. 1(4): 1152-1159.

5. Srivastava J, Lambert J and Vietmeyer N. 1996. Medicinal Plants: An Expanding Role in Development. Agriculture and Forestry Systems, World Bank, Washington DC.

6. Acharjee M, Jahan F, Rahman F and Noor R. 2013. Bacterial proliferation in municipal water supplied in mirpur locality of Dhaka City, Bangladesh. Clean Soil Air Water. 41: 1-8.

7. Dutta S, Hassan MR, Rahman F, Jilani, MFA and Noor R. 2013. Study of antimicrobial susceptibility of clinically significant microorganims isolated from selected areas of Dhaka, Bangladesh. Bangladesh $J$ Med Sci. 12(1): 34-42.

8. Djeussi DE, Noumedem JAK, Seukep JA, Fankam AG, Voukeng IK, Tankeo SB, Nkuete AHL and Kuete V. 2013. Antibacterial activities of selected edible plants extracts against multidrug-resistant Gramnegative bacteria. BMC Compl Altern Med. 13: 164.

9. Kucekova Z, Jiri M, Petr H and Otakar R. 2013. Edible flowers antioxidant activity and impact on cell viability. Central European $J$ Biol. 8(10): 1023-1031.

10. Ting A, Chow Y and Tan W. 2013. Microbial and heavy metal contamination in commonly consumed traditional Chinese herbal medicines. J Tradit Chin Med. 33(1): 119-24.

11. Oreagba IA, Oshikoya KA and Amachree M. 2011. Herbal medicine use among urban residents in Lagos, Nigeria. BMC Compl Altern Med. 11:117.

12. Rahmatullah M, Jahan R, Khatun MA, Jahan FI, Azad AK, Bashar ABM, Miajee ZUM, Ahsan S, Nahar N, Ahmad I and Chowdhury MH. 2010. A pharmacological evaluation of medicinal plants used by folk medicinal practitioners of Station Purbo Para Village of Jamalpur Sadar Upazila in Jamalpur district, Bangladesh. American-Eurasian $J$ Sustain Agri. 4: 170-195. 
13. Alfrad EB. 2007. Bensons Microbiological Applications. McGrawHill Book Company, New York.

14. Duraipandiyan V, Ayyanar M and Ignacimuthu S. 2006. Antimicrobial activity of some ethnomedicinal plants used by Paliyar tribe from Tamil Nadu, India. BMC Compl Altern Med. 6: 35.

15. Acharjee A, Fatema K, Jahan F, Siddique SJ, Uddin MA, Noor R. 2013b. Prevalence of Vibrio cholerae in different food samples in the city of Dhaka, Bangladesh. Int Food Res J. 20(2): 1017-1022.

16. Ahmed T, Baidya S, Sharma BC, Malek M, Das KK, Acharjee M, Munshi SK and Noor R. 2013. Identification of drug-resistant bacteria among export quality shrimp samples in Bangladesh. Asian J Microbiol Biotech Env Sci. 15(4): 31-36.

17. Hassan MR, Acharjee M, Das E, Das KK, Ahmed T, Akond MA, Fatema KK and Noor R. 2013. Microbiological study of sea fish samples collected from local markets in Dhaka City. Int Food Res J. 20(3): 1491-1495.

18. Noor R, Akhter S, Rahman F, Munshi SK, Kamal SMM and Feroz F. 2013. Frequency of extensively drug resistant tuberculosis (XDR-TB) among re-treatment cases in NIDCH, Dhaka, Bangladesh. J Infect Chemother. 19(2): 243-248. 